\title{
Aithaดูão
}

ISSN: 1984-6444 | http://dx.doi.org/10.5902/1984644438126

\section{A escrita no Centro Psychico de Caetité, Bahia: funções e usos (1905-1930)}

The writing in the Psychico Center of Caetité, Bahia: functions and uses (1905-1930)

Joseni Pereira Meira Reis

Professora doutora na Universidade do Estado da Bahia, Guanambi, Bahia, Brasil. josenimeira@gmail.com - https://orcid.org/0000-0003-3147-8106

Ana Maria de Oliveira Galvão

Professora doutora na Universidade Federal de Minas Gerais, Belo Horizonte, Minas Gerais, Brasil.

anamariadeogalvao@gmail.com - https://orcid.org/0000-0001-9063-8267

Recebido em 13 de maio de 2019

Aprovado em 13 de maio de 2020

Publicado em 28 de julho de 2020

\section{RESUMO}

Este trabalho buscou identificar e analisar quais eram os tipos e as funções da escrita no Centro Psychico de Caetité, Bahia, nas primeiras décadas do século XX. Inserese, assim, em um conjunto de estudos que busca compreender o papel de instâncias religiosas no letramento da população. Os estudos realizados nos âmbitos da história cultural, da cultura escrita e da história da educação nortearam a pesquisa teórica e metodologicamente. As fontes documentais, principalmente as que se encontram no arquivo da instituição, possibilitaram o seu desenvolvimento. O Centro foi fundado em 1905 por um grupo de homens pertencentes à elite econômica, política, social e cultural da cidade. Os resultados da pesquisa mostraram que a instituição mantinha intensa produção de materiais escritos, que foram produzidos por meio da escrita tanto manuscrita como impressa, com a utilização de suportes variados, como, por exemplo, atas, cartas, jornal e outros. Essa escrita atendia a duas principais dimensões: a espiritual, desempenhando as funções mediúnica, de assistência social e a homeopática; e a cotidiana, que estava voltada para as demandas da instituição e dos seus membros, expressas por meio das funções civil e pessoal, normativa, administrativa e de formação de redes de publicações. Assim, o Centro contribuiu, sobretudo por meio da divulgação da doutrina espírita, para aproximar e intensificar o contato dos adeptos com a cultura escrita.

Palavras-chave: História da cultura escrita; Instância religiosa; Século XX. 


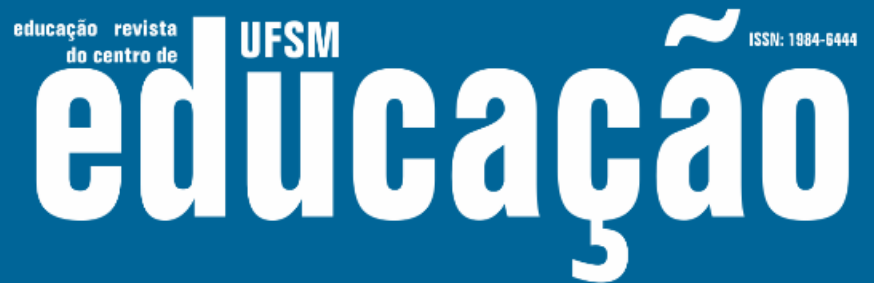

ISSN: 1984-6444 | http://dx.doi.org/10.5902/1984644438126

\begin{abstract}
This work sought to identify and analyze the types and functions of writing in the Psychic Center of Caetité, Bahia, in the first decades of the twentieth century. It is thus inserted in a set of studies that seek to understand the role of religious instances in the literacy of the population. The studies carried out in the field of cultural history, written culture and the history of education which guided the research theoretically and methodologically. The documentary sources, especially those that are in the file of the institution, enable its development. The Center was founded in 1905 by a group of men belonging to the city's economic, political, social and cultural elite. The research results showed that the institution maintained intense production of written materials, which were produced by writing both handwritten and printed, using various media, such as minutes, letters, newspaper and others. This writing dealt with two dimensions: the spiritual, performing the mediumship, social assistance and homeopathic functions; and the daily, which was directed to the demands of the institution and its members expressed through civil and personal, normative functions, formation of networks of publications between the periodical and administrative. Thus, the Center contributed, above all, to the spiritist doctrine, as well as to approach and intensify the contact of the adepts with the written culture.
\end{abstract}

Keywords: History of written culture; Religious instance; 20th century.

\section{Introdução}

Este artigo ${ }^{1}$ tem como objetivo identificar e analisar quais eram os tipos e as funções da escrita no Centro Psychico de Caetité$^{2}$, Bahia, entre 1905 e 1930, para compreender como essa instância religiosa colaborou no processo de letramento ${ }^{3}$ de seus adeptos. O período refere-se às décadas iniciais de funcionamento da instituição, fase marcada por desafios, enfrentamentos e avanços que contribuíram para o seu reconhecimento e consolidação junto à comunidade regional. $\mathrm{O}$ Centro foi fundado em 1905, por um grupo restrito de homens provenientes da elite econômica, política e cultural da cidade. É o caso, por exemplo, de Aristides Spínola que era proveniente de uma família de coronéis que exercia marcada influência política na região. $\mathrm{Na}$ época, ele desempenhava a função deputado federal e vice-presidente da Federação Espírita Brasileira.

Atas, estatutos, cartas, livros de receitas e despesas constituem as principais fontes de pesquisa. Os estudos realizados no âmbito da história cultural, da cultura escrita e da história da educação nortearam histórica e metodologicamente a pesquisa 


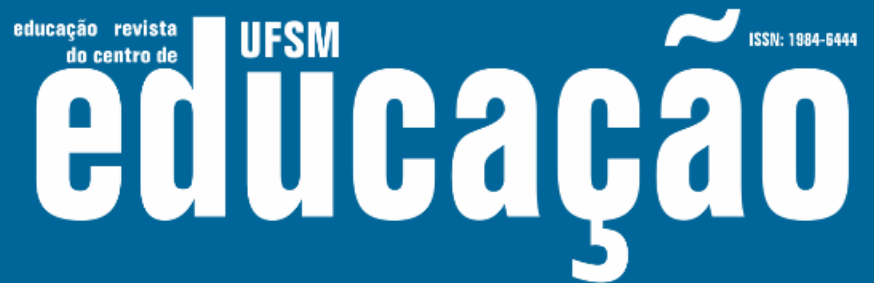

ISSN: 1984-6444 | http://dx.doi.org/10.5902/1984644438126

(CHARTIER, 2001, 2002; GALVÃO, 2007, 2010). O conceito de cultura escrita é pensado em uma dimensão antropológica, ou seja, como produto da atividade humana, resultado das interações da vida material e simbólica, sendo, portanto, "o lugar que o escrito ocupa em/para determinado grupo social, comunidade ou sociedade" (GALVÃO, 2010, p.218).

O estudo nos permitiu conhecer, compreender de que maneira o Centro contribuiu para aproximar e intensificar o contato dos adeptos com a cultura escrita. Nesse sentido, o trabalho insere-se em um conjunto de estudos que buscam compreender o papel de instâncias religiosas na alfabetização e no letramento da população. Há, pelo menos, quatro décadas, estudos vêm sendo realizados ${ }^{4}$, buscando correlacionar níveis de alfabetização de diferentes países à presença de distintas tendências religiosas entre a sua população ${ }^{5}$. Mais recentemente, outro grupo de pesquisas tem buscado compreender, por meio de estudos verticalizados e qualitativos, como as práticas religiosas atuam como agentes de letramento, configurando um tipo específico de relação com o escrito ${ }^{6}$. No caso brasileiro, no entanto, poucos trabalhos têm se dedicado a compreender essas questões. Raros ainda são as pesquisas ${ }^{7}$ que, ao debruçarem-se especificamente sobre comunidades, grupos e/ou indivíduos, buscam compreender o papel das práticas religiosas em sua participação na cultura escrita.

Embora o espiritismo seja considerado uma doutrina fundamentada na escrita ${ }^{10}$, sobretudo no caso brasileiro, poucos trabalhos dedicaram-se a compreender melhor essas relações. ${ }^{11}$ Desse modo, acreditamos que o presente estudo pode trazer contribuições para a área da História da Cultura Escrita no país uma vez que, tradicionalmente, as pesquisas tendem a analisar a escola como o principal - e às vezes - único espaço de mediação entre os sujeitos e a escrita (GALVÃO, 2010). Além disso, auxilia a compreender, de modo mais amplo, o papel de instâncias não escolares na formação da população. Embora existam diversos estudos no campo da História da Educação sobre o espiritismo, eles tendem a concentrar-se em espaços escolares, em intelectuais, em práticas educativas, entre outras. No geral, os estudos enfatizam o processo de implantação das instituições, os sujeitos e os fazeres que as 


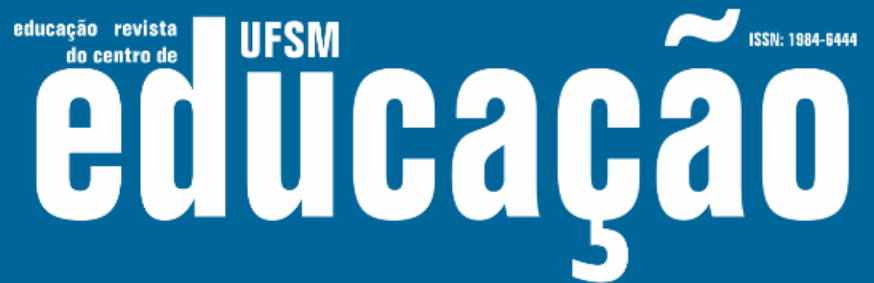

ISSN: 1984-6444 | http://dx.doi.org/10.5902/1984644438126

caracterizam como, por exemplo, o assistencialismo, o que evidencia as orientações religiosas disseminadas por essas instituições que se organizaram para educar, especialmente, as crianças pobres e desamparadas (BIGHETO, 2006; FUCKNER, 2009; GIL, 2013).

$\mathrm{O}$ artigo encontra-se organizado da seguinte forma: no primeiro momento, identificamos quais eram os espaços em que ocorriam eventos ${ }^{12}$ de letramento e os gêneros utilizados na produção da escrita no Centro. No segundo momento, mapeamos as funções desempenhadas pela escrita (por exemplo, mediúnica, espiritual, de assistência social, entre outras), buscando, ainda, apreender como e quem a produziu, e de que forma ela foi utilizada.

\section{Funções da escrita}

No Centro, os eventos de letramento aconteciam, principalmente, nas sessões ordinárias, nas conferências públicas e nas sessões comemorativas que envolviam a produção da escrita, do oral e do gestual. O Estatuto da instituição definia que as sessões ordinárias eram destinadas à formação na Doutrina Espírita e que tinham como escopo estudar o Espiritismo de forma teórica e prática, segundo os preceitos propostos nas obras de Allan Kardec. As conferências públicas tinham como objetivo divulgar a Doutrina Espírita para pessoas que ainda não frequentavam a instituição. Essas reuniões aconteciam quinzenalmente, geralmente aos domingos, e eram identificadas nas atas como sessões extraordinárias. Iniciava-se com a oração em voz alta, feita pelo diretor; em seguida, outro membro da diretoria apresentava a palestra que fora preparada antecipadamente, a qual costumava basear-se na leitura de um texto escrito, abordando temáticas pertinentes à doutrina. As sessões comemorativas ocorriam, especialmente, em 3 de outubro, dia em que se comemorava o nascimento de Allan Kardec, e em 25 de dezembro, dia do nascimento de Jesus Cristo, quando também se comemora a fundação do Centro em Caetité (ESTATUTO, 1928). Essas práticas faziam parte dos rituais estáveis da instituição. O evento festivo contava com 


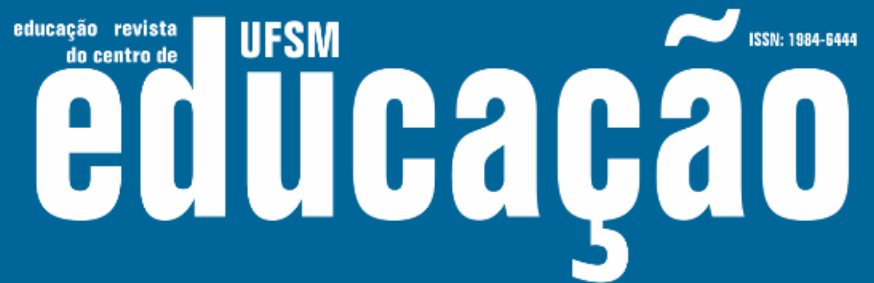

ISSN: 1984-6444 | http://dx.doi.org/10.5902/1984644438126

a intensa participação de crianças, em que se apresentavam várias atividades orais declamação de poesias, apresentação de jograis e músicas.

As atas e as cartas eram os tipos de suportes de escrita mais utilizados. Os associados compreendiam a relevância da escrituração para a existência legal da instituição, principalmente no que concerne à produção das atas, consideradas um documento jurídico. Por se tratar de uma escrita manuscrita de cunho oficial, seguia as normas e as regras definidas para esse gênero textual. Essa escrita era feita primeiramente em rascunhos em que constavam a data, os nomes das pessoas presentes e os principais pontos abordados na reunião. A seleção dos pontos mostra o que o redator considerava relevante registrar e era feita com o objetivo de lembrar as informações e impedir que elas fossem perdidas, sobretudo para preservar a memória ou história do grupo.

As cartas foram outro gênero textual de registro manuscrito utilizado como meio de comunicação. Elas cumpriram a função principal de manter o contato não somente entre os sujeitos e o Centro Psychico, mas também entre a instituição e outros centros espíritas do País e do exterior. Algumas eram de caráter público e tinham formas discursivas distintas, apresentando uma infinidade de usos. A prática de envio e recebimento de missivas remonta ao século XIX e pautou-se nos valores da sociedade burguesa ocidental, na qual se instituiu uma prática de comunicar com outros por meio da escrita, relatando os acontecimentos pessoais e do cotidiano (MALATIAN, 2009). Nelas, além das informações e notícias, destacam-se as ações de cordialidade e gentileza que alimentam as redes de sociabilidade.

Ao se pensar a funcionalidade interna da escrita (VIÑAO FRAGO, 1993) interessa identificar o que essa instância religiosa fez com a escrita, como ela foi utilizada. A escrita cumpria apenas a finalidade proselitista? Ou conseguiu expressar outras dimensões do seu cotidiano? Quais foram as funções dessa escrita na dimensão espiritual? 


\section{Bithapão}

ISSN: 1984-6444 | http://dx.doi.org/10.5902/1984644438126

\section{Função mediúnica}

Na Doutrina Espírita, a escrita mediúnica ${ }^{13}$ ocorre excepcionalmente por meio de uma manifestação espiritual, feita por intermédio de um médium. Allan Kardec ([1861] 2003) define, no Livro dos médiuns, que os medianeiros têm uma aptidão para fenômenos de diversas ordens, fato que resulta em tantas variedades quantas são as espécies de manifestações.

Para a sua produção era necessário um ambiente de oração e concentração, propicio à manifestação dos espíritos ${ }^{14}$, a qual poderia dar-se por meio da incorporação dos guias do próprio Centro ou de outros espíritos, no momento em que acontecia a comunicação, ou também por meio da oralidade e de práticas gestuais. Em algumas situações, os médiuns escreviam com certa facilidade; em outras, as manifestações podiam ocorrer em meio a tensões e conflitos com os espíritos, o que poderia dificultar a escrita dos médiuns, como pode ser percebido no relato: "começou a ler e, subitamente, foi apossado por um espirito que fel-o erguer-se do choque e denunciar que tratava-se de uma mystificação da medium ${ }^{15 "}$ (ACTA, 08/06/1906). Esse exemplo revela aspectos particulares da doutrina ao trazer questões sobre a disputa entre as "manifestações espirituais", possibilitando-nos, além disso, conhecer as condições de produção dessa escrita. Ao explicar o ocorrido, o redator mostrou como se davam as manifestações mediúnicas durante a produção da escrita e que os embates e atritos não se restringiam apenas ao plano terreno, mas estavam presentes e manifestavam-se, também, no plano espiritual.

A produção dessa escrita demandava uma organização e estruturação espacial, conforme relato do diretor: "Collocamos no centro da sala a mesa especial que mandamos fazer para esse fim, de forma elyptica, um pouco alongada. Em torno d'esta mesa formamos o primeiro circulo ou circulo interno" (ACTA, 09/08/1907). O relato destaca, ainda, a posição dos indivíduos na mesa: o centro era ocupado pelos médiuns práticos escreventes, do lado esquerdo os médiuns praticantes, e em torno deles os sócios presentes. A posição de cada um dos integrantes da mesa contribuía para a formação de uma corrente fluídica. A configuração do espaço para a sua 


\title{
N

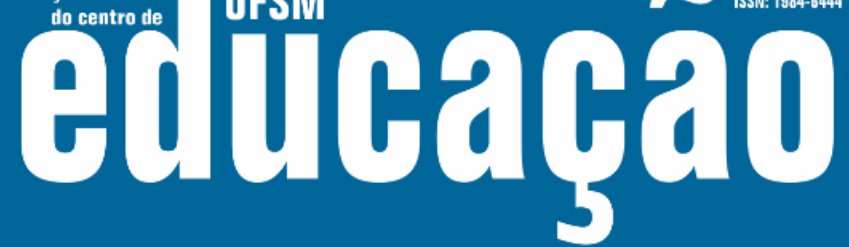

ISSN: 1984-6444 | http://dx.doi.org/10.5902/1984644438126

produção revela que as relações entre os médiuns escreventes e os praticantes estavam perpassadas pela hierarquização e pelas relações de poder.

A psicografia é considerada como parte do conjunto de crenças e práticas que se inserem no campo restritamente religioso. Para Ana Soares (2014), as mensagens e os textos provenientes desse processo são resultado da ação conjunta de médiuns e dos espíritos que encaminham mensagens de cunho religioso ou de edificação moral. Nessa produção, o médium pode recorrer ao uso de caracteres distintos e a estranhos movimentos gestuais.

Os relatos em ata evidenciam a necessidade de o Centro dispor de mais médiuns, especialmente o receitista. Tal demanda levou alguns membros a propor a criação de uma escola ${ }^{16}$, que seria um espaço destinado exclusivamente ao exercício da mediunidade. $O$ incentivo para a prática da mediunidade por meio da escrita justificava-se, com base em Kardec, que afirmava: "para o médium, a faculdade de escrever é, além disso, a mais suscetível de desenvolver-se pelo exercício" (KARDEC, [1861] 2003, p.255). A fala de Kardec ratifica a condição da escrita como uma habilidade que se aprende, portanto ela pode ser adquirida por meio de exercícios contínuos e sistemáticos que têm por base a repetição. A seguir, um dos médiuns do Centro Psychico explicita o modo como eram as práticas da escrita na escola de médiuns:

\begin{abstract}
tomaram papel e lapis diversos dos presentes para experimentarem a mediunidade. Nada conseguiram escrever, excepto o confrade Antonio Britto, que já [havia] praticado e obteve a seguinte mensagem escripta: 'A minha opinião é que deveis fazer em dias particulares esses exercicios, é justo que façam, porem em dia designado para este fim. Convem todos os vossos confrades e os assistentes tambem experimentar, pois pode ser que alguns tenham boas faculdades. Experimentar com vontade e firmeza. Podereis vós mesmos designar um dia da semana para estes exercícios ou, melhor, fazer escolas de mediuns, porem com grande criterio, pois do contrario, vós bem sabeis... Os vossos exercicios não devem ser de mais de meia hora, e em hora certa. (ACTA, 09/05/1916).
\end{abstract}

A escrita mediúnica foi um dos bens simbólicos responsáveis por aglutinar os novos adeptos na dinâmica do campo religioso espírita em Caetité, em função do seu capital de autoridade. A oferta dos bens simbólicos era uma forma de o Centro se 


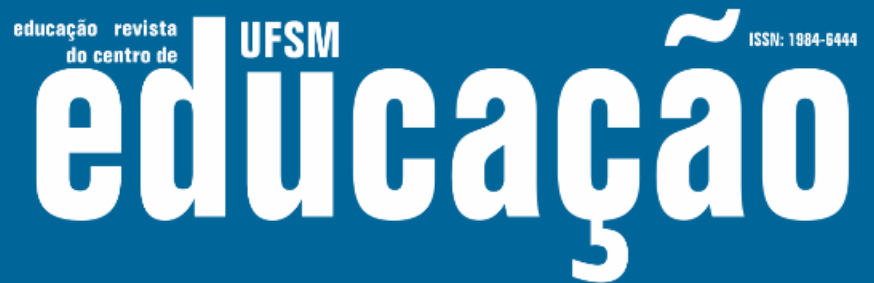

ISSN: 1984-6444 | http://dx.doi.org/10.5902/1984644438126

autoafirmar por meio do "exercício legítimo do poder religioso enquanto poder de modificar em bases duradouras as representações e as práticas dos leigos, inculcando-Ihes um habitus religioso" (BOURDIEU, 1992, p.57). Assim, as mensagens mediúnicas buscavam imprimir nos adeptos os preceitos e valores da doutrina, bem como a representação do mundo na perspectiva religiosa.

\section{Funções de assistência social e espiritual}

Nas funções de assistência social e espiritual, destacamos dois aspectos: as ações de assistência caritativa e as de assistência espiritual desenvolvidas pela instituição. Eram recorrentes os pedidos de auxílio financeiro e espiritual que chegavam ao Centro, a exemplo de uma carta enviada por uma senhora "honesta, na qual pede um auxilio semanal, por achar-se lutando com difficuldades para se manter" (ACTA, 17/02/1914). Além desse tipo de caridade feito pela instituição, alguns sócios sugeriram que deveriam destinar parte dos recursos adquiridos na aquisição de materiais escolares para crianças cujos pais estivessem desprovidos de recursos financeiros (ACTA, 15/03/1907). A opção por ajudar crianças a frequentarem a escola endossa a relação que existe entre o Espiritismo, a caridade e a educação escolarizada ${ }^{17}$.

Outro relato, identificado como explendido e instrutivo comunicado, cujo tema era Servir de pae aos orphãos. Nele, o médium falou longamente sobre a especulação que as pessoas fazem a título de caridade: "tomam para criarem os pobres orphãozinhos, fazendo-os verdadeiros escravos" (ACTA, 05/04/1920). A comunicação faz-nos pensar como eram tratadas as crianças adotadas pelas famílias caetiteenses e saber quais os serviços desempenhados por essas crianças. Ao fazer alusão à adoção dos órfãos para tratá-los como escravos, de alguma forma a mensagem posicionava-se contra tal prática e ao lado de um projeto social e político que circulava no Brasil republicano, buscando vincular a moralização da sociedade ao princípio espírita de progresso moral.

$\mathrm{Na}$ assistência espiritual, também foram recorrentes as solicitações que chegavam por meio de cartas. Essas geralmente tratavam de casos de pessoas que 


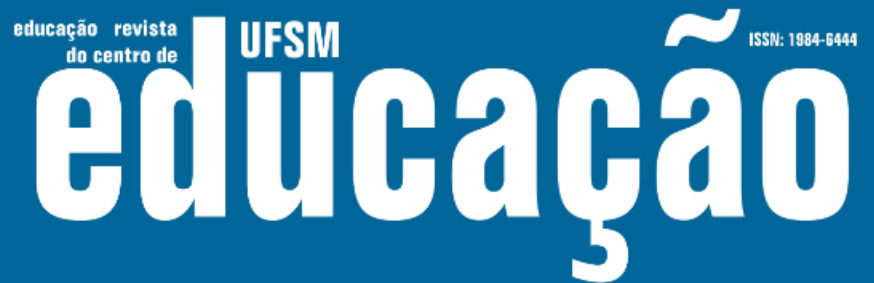

ISSN: 1984-6444 | http://dx.doi.org/10.5902/1984644438126

diziam estar obsediadas ${ }^{18}$, possuídas, necessitando, portanto, da intervenção espiritual dos médiuns para ajudá-las a resolver os problemas. Na maioria das vezes, tais pessoas encontravam-se perturbadas mentalmente e, em crises convulsivas e se batiam. Os pedidos de assistência espiritual eram provenientes da cidade de Caetité, Minas do Rio de Contas, Monte Alto, Guanambi, Bonito (Igaporã), Bom Jesus da Lapa e de outras cidades da região do Alto Sertão da Bahia.

\section{Função de difusão de saberes da homeopatia ${ }^{19}$}

Difundir os saberes foi outra função da escrita, especialmente por meio da homeopatia e da prescrição de remédios. Para Damazio (1994), a expansão do Espiritismo no Rio de Janeiro, no final do século XIX, vinculou-se à prática homeopática exercida pelos médiuns. Essa prática também se fez presente em Caetité e era vista pelos espíritas como uma oportunidade de alavancar o crescimento da doutrina, na medida em que os resultados das possíveis curas serviam para propagá-la e divulgá-la. Ficou acordado entre os membros que trariam ao Centro "mediuns videntes, auditivos etc, mandar-se vir como já tratou-se aqui anteriormente um scriptoscopio ${ }^{20}$ [...], fazer a aquisição de uma pequena pharmacia homeopathica" (ACTA, 22/02/1910). Isso demonstra a preocupação dos adeptos em dispor na instituição das condições espirituais (médiuns específicos), materiais e recursos tecnológicos da época, necessários à prática do Espiritismo. O interesse em adquirir um aparelho como o scriptoscopio revela de certa forma um dos valores que mobilizavam o grupo em torno das questões de ordem psíquica que demandavam investigação e experimentação dos fatos. Seria essa uma estratégia utilizada como uma forma de atrair adeptos para a doutrina? Seria uma tentativa de aproximar-se de uma perspectiva científica?

Entretanto, a instituição também enfrentou dificuldades para implementar a prática da homeopatia, notoriamente por causa de suas limitações orçamentárias e principalmente pela falta de um médium receitista ${ }^{21}$ capaz de fazer as indicações dos medicamentos. Além disso, essa dificuldade estava inscrita numa condição 


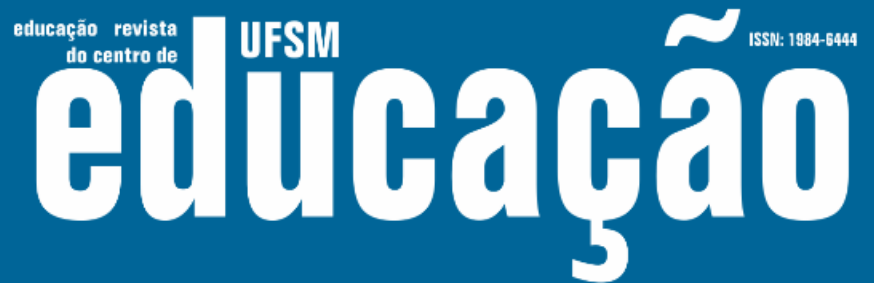

ISSN: 1984-6444 | http://dx.doi.org/10.5902/1984644438126

conjuntural que envolvia a prática desse saber no Brasil. Apesar das contingências, numa breve e incisiva manifestação espiritual, o guia Santa Júlia aconselhou-os que deveriam "montar a pequena pharmacia homeopathica" (ACTA, 25/02/1910). Na escrita contábil da instituição constata-se que, entre os anos de 1921 e 1930, intensificaram-se as despesas com a farmácia homeopática.

No Brasil, a homeopatia enfrentou dificuldades ${ }^{22}$ na medida em que a incorporação da prática pelos médiuns receitistas desencadeou fortes tensões e embates com a medicina alopática, desejosa de manter o controle do campo de atuação. Igualmente houve embates com a polícia, encarregada de cumprir o Código Penal de 1890, que, em seu Capítulo III (Dos crimes contra a saúde pública), artigos 156, 157 e 158, estabelecia penalidades e proibições quanto à prática do espiritismo, da magia e outros sortilégios, assim como à prática da medicina por leigos ${ }^{23}$.

As dimensões da escrita no cotidiano da instituição incorporavam outras funções de ordem pragmática e normativa. Vejamos quais eram:

\section{Função de ordem civil e pessoal}

$\mathrm{Na}$ função civil, identificamos os comunicados referentes aos nascimentos ${ }^{24}$, casamentos e falecimentos, ritos que marcam determinadas fases da vida, alguns dos quais foram construídos histórica e culturalmente pelas práticas da comunidade e que servem para definir o início, a passagem ou o final de uma fase. A cultura ocidental, sob influência do Catolicismo, imprimiu alguns rituais que foram incorporados e disseminados pelas comunidades locais, a exemplo do batismo da criança recémnascida. No Centro, existia o interesse dos sócios em registrar o nascimento das crianças. Geralmente a iniciativa partia da própria direção, como no caso em que o diretor João Gumes: "expoz para á Casa o desejo que tinha de fazer em sessão a declaração de nascimento de seu filhinho, com o nome do recemnascido e dos paranynphos" (ACTA, 20/09/1907).

Registrar em ata o nascimento da criança e indicar os nomes dos seus paraninfos evidencia uma ritualização do momento. Essa prática reporta-nos ao 


\section{N \\ Futbap̧a}

ISSN: 1984-6444 | http://dx.doi.org/10.5902/1984644438126

sacramento do batismo utilizado pela Igreja Católica, que simboliza o início da vida cristã do indivíduo. Entretanto, tal fato não foi isento de tensão em relação aos valores defendidos pela Doutrina Espírita. O anúncio do nascimento de uma criança, a seguir, mostra a preocupação em se definir qual o seu sentido:

o nosso confrade Francisco Fernandes communicou a todos o nascimento do seu filho Carlos, e em seguida consultou à casa se poderia apresentar ao Centro o recemnascido, dando como paraninphos os consocios Francisco Cotrim e D. Laura Gumes. Apoiada unanimemente a sua proposta, mandou o director que se consignasse na acta, ficando assim o registro do nascimento do pequeno Carlos e os seus paraninphos, que, embora não seja este registro um acto symbolico, que a nossa doutrina repelle, fica entretanto de alguma forma a obrigação de encaminharem o pequeno confiando a sua protecção espiritual, no itinerario dos principios da doutrina espirita. (ACTA, 21/02/1908).

Da atitude do membro, conclui-se que o redator quis ressaltar que 0 comunicado do nascimento da criança, seguido dos nomes dos paraninfos, não guarda proximidade com 0 ato do batismo realizado pelos católicos. Todavia, 0 registro revela que há uma tensão entre uma prática que se aproximava de um ritual simbólico, utilizado pelos católicos, e o sentido que esse gesto tinha para os espíritas. Evidencia, também, a relevância da dimensão pública dessa escrita para esse grupo de espíritas, uma vez que, no Brasil, o documento do batismo da criança, batistério, teve durante muito tempo valor jurídico ${ }^{25}$, substituindo o próprio registro de nascimento.

A escrita na ata comunicando o nascimento de uma criança e os nomes dos seus paraninfos não foi uma questão resolvida de forma tranquila entre os espíritas. Havia, por parte dos participantes, o receio de que essa ação deparasse com as críticas provenientes dos católicos, dando a entender que os espíritas estavam apropriando-se de uma prática utilizada por eles, uma vez que, para a religião católica, o batismo, além de ser um ato civil, é também um sacramento.

Considera-se a prática dos registros de nascimento feita pelos espíritas como resultado de um processo de mestiçagem cultural, pois "nada é inconciliável, nada é incompatível, mesmo se a mistura é por vezes dolorosa" (GRUZINSKI, 2001, 


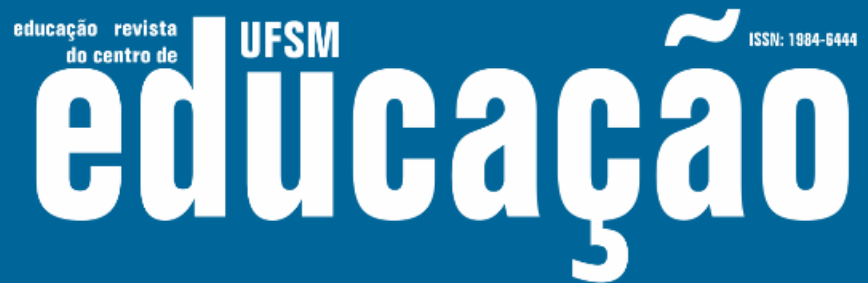

ISSN: 1984-6444 | http://dx.doi.org/10.5902/1984644438126

p.28). Isso mostra a capacidade que têm os grupos de eleger e de combinar certos elementos entre as culturas, sobretudo as condições de adequaremse e adaptarem-se a uma nova realidade. Assim, registrar em ata de reunião do Centro o nascimento da criança, acompanhado dos nomes dos paraninfos, apresenta relação com um pertencimento religioso. Entretanto, essa prática não se restringe, apenas, a um único espaço, mas pode apresentar-se num outro lugar sob uma nova configuração. Ao incorporar e ressignificar alguns elementos do batismo realizado pela Igreja Católica, os espíritas atribuíam a ele um novo sentido, como, por exemplo, não utilizaram os termos batismo e padrinho. Em seu lugar, optaram pelo uso de comunicado e registro do nascimento da criança e paraninfos. Dessa forma, pode-se dizer que essas práticas sociais estavam imbricadas nos indivíduos em função das instâncias formadoras às quais estavam vinculados, se considerarmos que os sujeitos influenciam os processos de socialização dos quais participam e por eles são influenciados.

O casamento também foi outro marco referencial da vida civil tratado na documentação, em que adeptos da doutrina queriam compartilhar com seus pares a auspiciosa notícia: "Communica a irmã e socia Mariana Gumes, que havia realizado consorcio com o Sr. José Soares também crente, que se acha presente" (ACTA, 09/09/1910). Os comunicados referentes aos marcos temporais da vida dos adeptos costumavam atravessar as gerações de uma família, como, por exemplo, o do vicediretor, Marcelino Neves, que "participou o casamento de sua filha Maria Regina Neves com o Sr. José Troiano de Freitas" (ACTA, 02/02/1915). Posteriormente, a filha comunica o nascimento dos filhos e depois o casamento destes. Existe ainda nota que informava a não realização de evento que fora previamente noticiado: "achava-se desfeito o contracto de casamento de sua filha com Luis Philogonio Vieira; que julgava ser seu dever participar aos confrades este occorrido por há mezes ter communicado o contrato entre os mesmos" (ACTA, 14/07/1911).

$\mathrm{Na}$ função pessoal, há ainda os registros de despedidas, falecimentos e os relativos à própria participação na instituição. As despedidas dos confrades e das confreiras o fazem em função de: mudança da cidade, viagens temporárias, doença, 


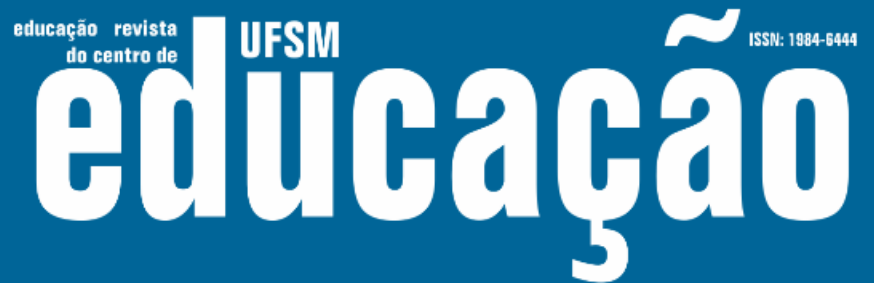

ISSN: 1984-6444 | http://dx.doi.org/10.5902/1984644438126

passeio, trabalho e outros. Entre os registros encontra-se o comunicado do irmão Aristides Públio, em que este pede à plenária permissão "para despedir-se, pois tendo de ausentar-se por muitos dias d'esta Cidade, em uma viagem á Bahia [Salvador] em procura de melhoras para o seu sobrinho Everardo que acha-se doente" (ACTA, 01/08/1924).

Os informes ou comunicados, antes de serem inscritos em ata, eram submetidos à aprovação da assembleia, conforme se evidencia: "Propoz o director e foi aprovado que constasse em acta a desencarnação do capitão Pedro Castro, pai de nosso confrade Arnobio Castro, [...]" (ACTA, 25/04/1910). Os registros não se restringiam às pessoas próximas, ou que possuíam vínculo de parentesco com membros do grupo. Por vezes, abrangiam sujeitos que, de alguma forma, prestaram algum serviço relevante à Doutrina Espírita ou à sociedade de uma maneira em geral. As citações mostram como as ações da oralidade e da escrita estão fortemente entrelaçadas nesse espaço. Antes de ocorrer o registro escrito, o pensamento era expresso em voz alta, comentado pelo grupo e, quando aprovado, a depender dos interesses em questão, era posto em ata.

Outros usos da escrita na dimensão pessoal serviam para justificar a ausência de membros às sessões. As atas informam que ao Centro foram enviadas dez missivas. Dessas, cinco atribuíam a ausência a motivos particulares, três alegavam ausência por motivo de doença, e duas por motivo de viagem. Apenas uma delas foi conservada dentro do livro de atas. Escrita em 1906, a missiva do secretário, João Gumes, explica o motivo e a justificativa da sua ausência nas reuniões, que se deu por "forças das dolorosas circunstancias que afastaram-me temporariamente do vosso meio, mas isso não arrefece o meu amor pela Santa causa da verdade e o interesse que devo ligar à propaganda de que fomos incumbidos ${ }^{26 " . ~ A s s i m, ~ n u m a ~ l o n g a ~}$ narrativa, o redator fala do seu ânimo em ver como a doutrina em Caetité estava avançando e enraizando-se nos corações dos adeptos. Entretanto, destaca as dificuldades que enfrentavam para a divulgação do Espiritismo: "bem sei; porem o modus faciendi, isto é, o meio practico de diffundir a luz não está as mais das vezes ao alcance da razão, quando está alto o dominio sobre o temperamento 27 ". 


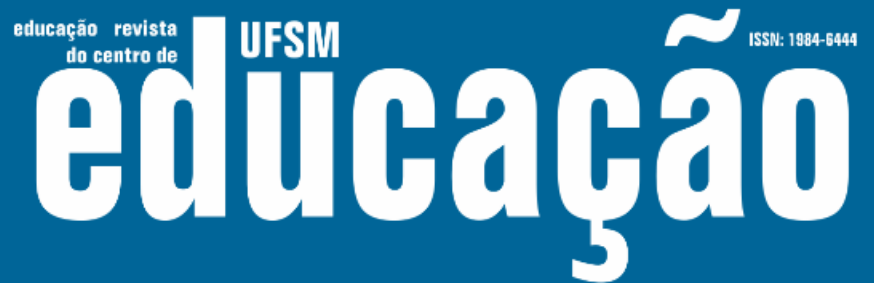

ISSN: 1984-6444 | http://dx.doi.org/10.5902/1984644438126

Ainda na perspectiva da dimensão pessoal, os membros da instituição utilizavam a escrita para renunciar aos cargos e desligar-se do Centro. Assim, identificamos cinco cartas de renúncia e duas de desligamento. Entre as de desligamento, quatro são de membros que agradecem pela votação e pela escolha de seus nomes para ocuparem cargos na agremiação, mas dizem que, infelizmente, não se acham em condições de exercê-los. Em uma das missivas, além de se desligar, o autor Edésio Santos abjura da Doutrina Espírita, constando em ata que: "depois de narrar uma porção de sandices, concluiu confessando de ter abjurado a crença, e pouco satisfeito com isto, ainda aconselhava com toda energia ao nosso irmão Elgino para com elle desencaminhar-se" (ACTA, 29/09/1911).

Quanto ao desligamento das atividades do Centro, o vice-diretor escreve uma carta em 1911, em que justifica o seu desligamento como temporário e por questões particulares. Outra carta, remetida pelo ex-confrade Francisco Fernandes Lima, afirma que o motivo da sua saída é "a execranda perseguição que me faz o representante do catholicismo jesuitico n'esta cidade" (ACTA, 30/08/1912). Ao final da longa missiva, Francisco Lima solicita: "Peço para exarar essa [carta] na acta a fim de que no futuro conheçam o motivo da minha deserção do mesmo" (ACTA, 30/08/1912).

Outras escritas na dimensão pessoal trazem ainda o relato de atritos entre membros. Fatos que parecem irrelevantes conduziram a desentendimentos; tem-se, por exemplo, o registro integral de duas cartas de abril de 1913, em que o diretor e o confrade Antônio Marcellino Neves são envolvidos numa contenda (ACTA, 21/04/1913). Ambos buscam, nas suas narrativas sobre o acontecido, explicar o que os levou a tal desentendimento. Fica evidente que são questões de ordem pessoal e subjetiva. Os motivos que levaram a tal desentendimento não foram mencionados nas cartas. Talvez pela falta de algo plausível, o desentendimento tenha sido temporário, uma vez que Marcelino das Neves continuou assíduo às reuniões do Centro. $O$ fato revela ainda que os registros em ata não selecionavam apenas as boas e notáveis ações dos sujeitos, mas evidenciaram, também, os conflitos em torno dos micropoderes presentes nas relações dos seus membros. 


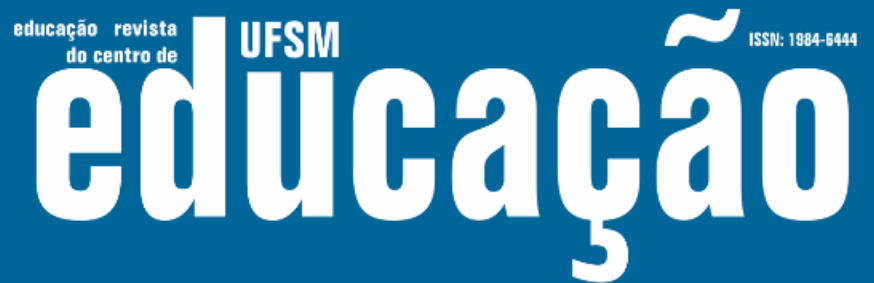

ISSN: 1984-6444 | http://dx.doi.org/10.5902/1984644438126

Os registros em ata tratam, sobretudo, de questões referentes à atuação de pessoas que contribuíram com o reconhecimento, a divulgação e a expansão do Espiritismo. Fica evidente também que, seja na produção das atas, seja na produção das cartas, há um espaço destinado para o registro das questões pertinentes à comunidade que envolvem as dimensões do fazer e do viver (CERTEAU, 2001), reveladoras das pulsações das dinâmicas vividas em toda a sua intensidade. Esses relatos mostram aspectos do cotidiano dessa comunidade, as tensões, os conflitos, as divergências, as vaidades e os dilemas que permeavam as relações dos sujeitos, relações essas marcadas pelas disputas e interesses, fossem de ordem pessoal, social, política ou religiosa que se refletiam na instância religiosa.

\section{Função normativa}

A escrita normativa ocupava lugar de destaque, sobretudo porque nela definiam-se as normas legais, os comportamentos e as ações que regulavam e orientavam o funcionamento do Centro. Uma das primeiras proposições nessa perspectiva foi a elaboração de um estatuto ${ }^{28}$, conforme relato: "foi apresentado um esboço de estatuto que lido, a pedido do apresentante, será submettido a um estudo previo, afim de emendado e alterado como convier, ser justo a estes" (ACTA, 06/03/1906). A redação desse documento demandou um longo processo de discussão, que prosseguiu nos anos posteriores.

A escrita normativa definiu, ainda, a prescrição de ações, comportamentos e atitudes considerados adequados aos adeptos da doutrina. Era orientada pelas mensagens espirituais, como define a ata "para o conhecimento d'quelles que ainda não tinham ouvido, na qual acham-se transcritas as regras de conducta que devem ser observadas por aquelles que assistirem as sessões" (ACTA, 06/02/1906). Sempre que necessário essas questões eram retomadas por meio da leitura da ata feita em voz alta de forma coletiva, como uma forma de relembrar, rememorar e atualizar uma norma que havia sido emitida, em outro momento, pelos guias do Centro. Assim, os 


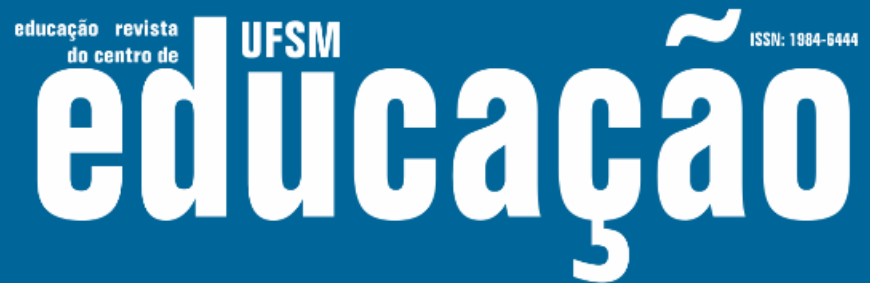

ISSN: 1984-6444 | http://dx.doi.org/10.5902/1984644438126

espíritos detentores de autoridade eram os responsáveis por indicar as ações do núcleo religioso.

As mensagens mediúnicas foram enfáticas em observar a frequência e a pontualidade dos adeptos às sessões. Um relato em ata revela que, independentemente da ausência do diretor e do vice, a sessão ordinária iniciava-se conforme o horário previsto, às 19h30min, e informava que um dos membros evocou um espírito auxiliar para conduzir os trabalhos mediúnicos: "manifestaram-se trez espíritos que, recomendava muita ordem, respeito e amor, lastimando o arrefecimento que vai lavrando, patenteando a nossa ignorancia da verdadeira doutrina e a necessidade de instruirmo-nos"29. O seguinte relato notifica uma interrupção durante a manifestação e destaca: "Nesse interim, chegando o diretor Lima Júnior, bateu na porta, dando lugar a desviar-se-nos a atenção do trabalho, sendo suspensa a terceira revelação" (ACTA, 14/04/1906). Na regulação dos comportamentos, os espíritos advertiam quanto à ausência e a negligência dos associados e uma manifestação censurou "brandamente a ausencia dos associados que não compareceram a esta sessão solenne" (ACTA, 14/04/1911).

As manifestações dos guias espirituais, bem como dos dirigentes mostravam preocupação explícita em doutrinar os comportamentos dos membros, a partir do controle da fala, do corpo ${ }^{30}$ e dos gestos, como mostra a passagem: "mais uma vez chamou-nos attenção para a falta de respeito e atenção notou-se tratarmos aqui no Centro de assumptos alheios ao Espiritismo, o que nos acarretaria maus resultados" (ACTA, 27/07/1906). No processo de educação e controle dos comportamentos, as mensagens enviadas pelos espíritos cumpriam função essencial. Afinal, tratava-se de entidades que se encontravam num nível mais elevado em relação aos adeptos da doutrina, por isso detinham poder e autoridade. Sobre a relação entre corpo e linguagem, os estudos de Bourdieu (1983) mostram que o capital linguístico é incorporado. O aprendizado da língua vincula-se a um aprendizado de um esquema corporal, visto que ele, assim como a língua, faz parte das experiências imediatas. Portanto, a linguagem reflete uma determinada postura corporal que indica uma relação de pertencimento a uma classe social. Nesse sentido, a Doutrina Espírita 


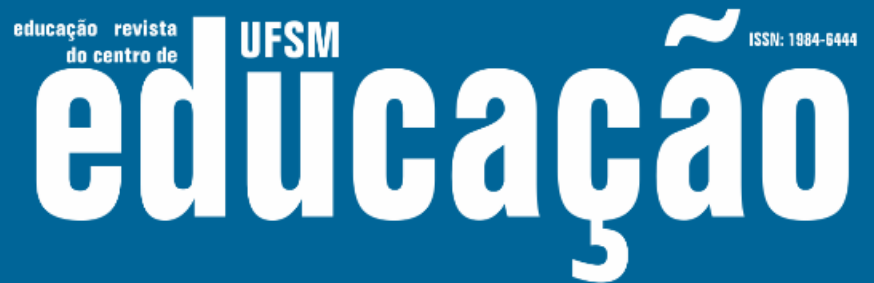

ISSN: 1984-6444 | http://dx.doi.org/10.5902/1984644438126

exercia certa forma de regulação e controle da linguagem e da postura corporal dos seus adeptos. Não bastava apenas ter domínio dos seus princípios, mas o domínio do conhecimento religioso, que implicava a forma correta de utilizar a linguagem, bem como conversar com polidez (AGULHON, 1989), condições necessárias para fazer parte do grupo.

Desde o final do século XIX e início do XX, questões sobre educação, estudo, instrução e progresso presentes nos debates travados pelos intelectuais na imprensa, davam a dimensão da sua relevância. No Centro Psychico, essas questões estiveram igualmente presentes, sendo recorrentes no Livro de manifestações dos espíritos os termos instruir ${ }^{31}$ e educar, denotando a dimensão pedagógica da Doutrina Espírita e os ideais educativos de Allan Kardec ([1861]2003). Em uma das atas, verifica-se: "instruí com amor e caridade os vossos irmãos que quiserem abraçar essa crença"; "cuidar muito em instruir todos aqueles que desejam ser admitidos como sócios" (ACTA, 09/01/1906).

\section{Função de formação de redes de publicações entre os periódicos}

A função de formação das redes de publicações entre os impressos foi outra dimensão igualmente relevante da escrita na instituição. Os laços formados entre a direção do Centro e pessoas, instituições, jornais espíritas de vários estados do Brasil e do mundo eram alimentados por meio do envio e recebimento de cartas, de convites ou exemplares de jornais.

A dimensão social da escrita é revelada pelo intenso e profícuo contato que a instituição manteve com outros centros, tanto no Brasil como fora do País, especialmente por meio de cartas, as quais somaram um total de 152. Desse total, 86 foram enviadas por grupos espíritas de diferentes estados, comunicando a eleição e posse da nova diretoria, como pode ser observado: "foram lidas [...], as seguintes cartas: do Centro Seara de Jesus, de Juiz de Fóra, Minas Gerais, communicando a eleição e posse da sua directoria; da União Espirita com séde em Bello Horizonte, agradecendo communicação" ${ }^{32}$. O Centro Psychico manteve, ainda, relações com 


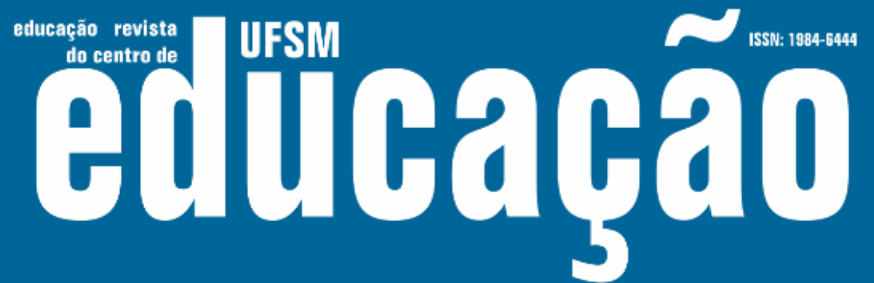

ISSN: 1984-6444 | http://dx.doi.org/10.5902/1984644438126

centros espalhados por mais de dez estados do Brasil; o maior número de correspondências recebidas vinha do Rio de Janeiro (21 missivas), seguido de São Paulo e Espírito Santo, com 13 de cada um, e Minas Gerais, com sete. Dos demais estados foi enviado um número menor de missivas. Do Maranhão, por exemplo, foi recebida apenas uma correspondência.

Vale destacar que as redes de sociabilidade mantidas pelo Centro não se limitavam às instituições espíritas, envolviam também outras agremiações, como, por exemplo, associações literárias. Consta nas atas o recebimento de correspondência enviada pelo "Club Rio Contense da cidade de Minas do Rio de Contas em nosso estado, communicando-nos a sua nova Directoria" (ACTA, 20/01/1931).

\section{Função administrativa ou contábil}

A função administrativa ou contábil diz respeito à escrituração dos registros dos recursos para a manutenção do Centro. Esses registros mostram a origem das doações em espécie feitas pelos adeptos, dos pagamentos da joia pelos associados, das coletas quinzenais, da assinatura do jornal $L u x$, dos gastos com aquisição de materiais diversos e do auxílio financeiro a pessoas carentes. No Livro de receitas e despesas do período de 1907-1957, constam os valores das contribuições recebidas e as despesas efetivadas. Percebe-se que, nos anos iniciais de seu funcionamento há um cuidado em especificar as despesas realizadas; posteriormente, os registros vão-se tornando escassos, havendo a preocupação de registrar apenas os valores arrecadados nas coletas e as doações recebidas.

Os recursos para a manutenção da associação deveriam vir das contribuições dos sócios. O Estatuto, no seu artigo 7ํㅡㄹ define que os sócios inscritos são obrigados, a partir da sua admissão, ao pagamento de uma joia no valor de $5 \$ 000$ (cinco mil réis) e a contribuir mensalmente com a coleta. Além disso, estipulou, em seu art. $7^{\circ}, \S^{\circ} \stackrel{\circ}{ }$, que a "quantia não seja inferior a 500 reis por cada uma, ou quando não estiverem presentes as sessões de collectas, recolher $1 \$ 000$ por cada mez" (ESTATUTO, 05/06/1928). O Centro era formado por pessoas de diferentes condições econômicas, 


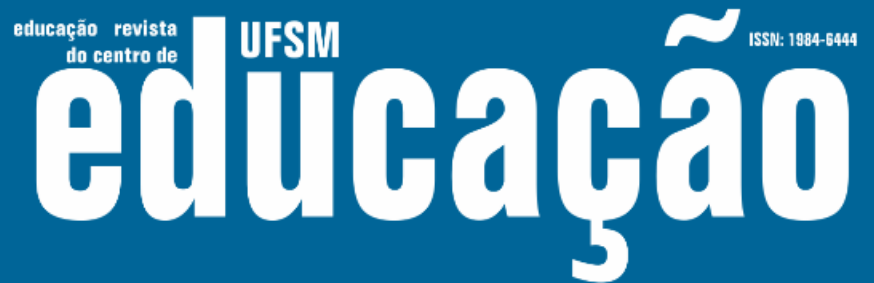

ISSN: 1984-6444 | http://dx.doi.org/10.5902/1984644438126

sendo tal fato levado em consideração nos momentos de decisão sobre a contribuição financeira dos membros. Aos médiuns era facultada a contribuição, uma vez que eles prestavam relevantes serviços à instituição, "como intermediarios entre o centro e o mundo invisivel através da escrita" (ACTA, 19/01/1906).

$\mathrm{Na}$ escrita contábil da instituição, é possível verificar que, nos anos iniciais de seu funcionamento, as contribuições eram frequentes e de valores elevados, o que possibilitou a construção de um novo edifício para a sede, executada no período de um ano. Posteriormente, a instituição passou por um período de dificuldades financeiras, talvez em função da diminuição do número dos frequentadores e, consequentemente, de contribuintes. Nesse ínterim, foi relevante, para a continuidade das atividades, o auxílio financeiro proveniente das famílias espíritas, principalmente as de maior poder econômico.

\section{Considerações finais}

O estudo permitiu revelar aspectos da história da cultura escrita e da história da educação ainda pouco investigados no Brasil, evidenciando que outras instâncias, além da família e da escola, como, por exemplo, as práticas religiosas, atuaram como agentes de letramento, configurando um tipo específico de relação com o escrito, como foi o caso do Centro Psychico de Caetité. Nele havia intensa produção da escrita manuscrita e impressa com a utilização de variados suportes, como atas, cartas, livro da farmácia homeopática, jornal, entre outros. É possível afirmar ainda que a escrita produzida atendeu a uma funcionalidade intrínseca à doutrina, ou seja, a funções que eram então associadas à dimensão religiosa: mediúnica, de assistência social e espiritual e a difusão de saberes da homeopatia.

A produção da escrita mediúnica reflete a especificidade dessa instância, a presença de um ethos religioso, expresso por meio da psicografia. Os usos decorrentes dessa escrita visavam, sobretudo, atender aos preceitos em proporcionar o conforto físico, espiritual e moral daqueles que recorriam ao auxílio da instituição. Outro aspecto dessa escrita envolvia a funcionalidade interna (VIÑAO 


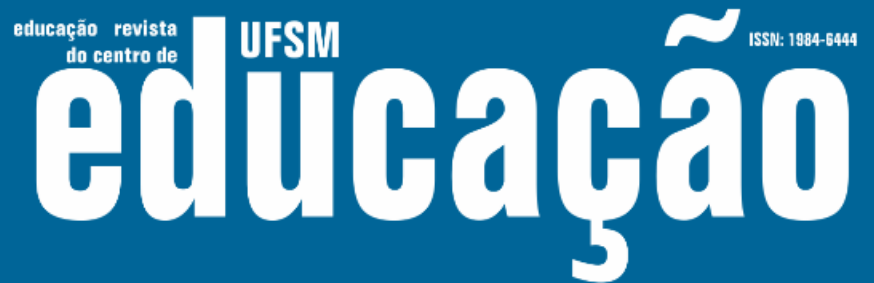

ISSN: 1984-6444 | http://dx.doi.org/10.5902/1984644438126

FRAGO, 1993), visto que partia da necessidade de seus adeptos em atender a demandas de naturezas diversas: funções de ordem civil e pessoal, normativa, formação de redes de publicação entre os periódicos e a contábil. A escrita aí produzida também atendeu às demandas da dimensão cotidiana, registrou cenas ordinárias do fazer e do viver (CERTEAU, 2001) do grupo e da comunidade local e regional. Assim, além de cumprir os objetivos aos quais se destinavam esses saberes, buscava, sobretudo, difundir o proselitismo religioso e conquistar adeptos para a doutrina.

\section{Referências}

AGULHON, Maurice. As sociedades de pensamento. In: VOVELLE, Michel. França Revolucionária (1789-1799). São Paulo: Brasiliense; Secretaria de Estado da Cultura, 1989.

ARAÚJO, Fernanda Nascimento de. Nadando Contra a Corrente: a Homeopatia e seus embates na Bahia através da trajetória de Alfredo Soares da Cunha (1913 1936). Dissertação (Mestrado), Programa de Pós-Graduação em História das Ciências e da Saúde, Casa de Oswaldo Cruz-Fiocruz, Rio de Janeiro, 2015.

ARRIBAS, Célia da Graça. Afinal espiritismo é religião?: A doutrina espírita na formação da diversidade religiosa brasileira. São Paulo: Alameda, 2010.

AUBRÉE, Marion; LAPLANTINE, François. A mesa, o livro e os espíritos: gênese, evolução e atualidades do movimento social espírita entre França e Brasil.

Tradução: Maria Luiza Guarnier et al, Maceió: EDUFAL, [1990]2009.

BARTON, David. The social nature of writing. In: BARTON, David; IVANIC, Rosalind (Eds.). Writing in the community. London: Sage, 1991, p.1-13.

BIGHETO, Alessandro Cesar. Eurípedes Barsanulfo: um educador espírita na Primeira República. Dissertação (Mestrado), Faculdade de Educação da UNICAMP, Campinas/SP, 2006. Disponível em:

http://www.repositorio.unicamp.br/jspui/bitstream/REPOSIP/.../1/Bigheto_Alessandro Cesar_M.pdf. Acesso em: 21 fev 2015.

BOURDIEU, Pierre. A economia das trocas simbólicas. São Paulo: Perspectiva, 1992. 


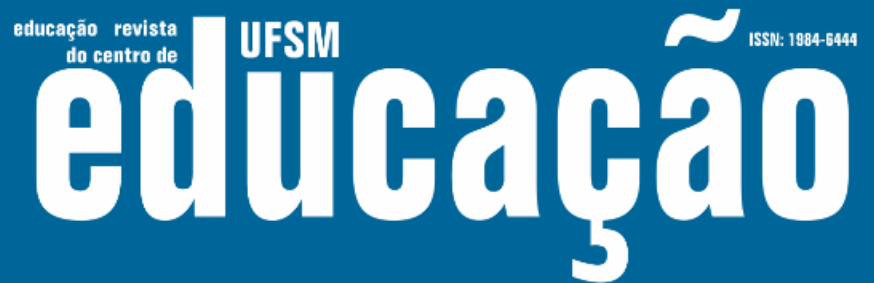

ISSN: 1984-6444 | http://dx.doi.org/10.5902/1984644438126

BOURDIEU, Pierre. A economia das trocas linguísticas. In: ORTIZ, R. (Org.). Pierre Bourdieu: sociologia. São Paulo: Ática, 1983.

CARNEIRO, Giane A. Pimentel. As práticas educativas familiares no processo de distinção geracional criança/adulto (Caetité-BA, 1910-1930). Dissertação (Mestrado), Programa de Pós-Graduação em Educação, Conhecimento e Inclusão Social, Universidade Federal de Minas Gerais, Belo Horizonte, 2011. Disponível em: http://www.bibliotecadigital.ufmg.br. Acesso em 15 mar. 2015.

CASTILLO, Lisa E. Entre a oralidade e a escrita: a etnografia nos candomblés da Bahia. Salvador: EDUFBA, 2010.

CAVALCANTI, Maria Laura V. de Castro. O mundo invisível: cosmologia, sistema ritual e noção de pessoa no espiritismo. Rio de Janeiro: Centro Edelstein de Pesquisa Social, [1983] 2008. Disponível em: http://books.scielo.org. Acesso em: 12 ago. 2017.

CERTEAU, Michel. A Invenção do Cotidiano: artes de fazer. 6 ed. Rio de Janeiro: Vozes, 2001.

CHARTIER, R. Cultura escrita, literatura e história: Conversas de Roger Chartier com Carlos Anaya, Jesús Anaya Rosique, Daniel Goldin e Antônio Saborit. Porto Alegre: Artmed, 2001.

CHARTIER, R. Os desafios da escrita. Tradução Fúlvia M. L. Moretto. São Paulo: UNESP, 2002.

DAMAZIO, Sylvia F. Da elite ao povo: advento e expansão do Espiritismo no Rio de Janeiro. Rio de Janeiro: Bertrand Brasil, 1994.

DEL PRIORE, Mary. Do outro lado: a história do sobrenatural e do espiritismo. São Paulo: Planeta, 2014.

DENIPOTI, Cláudio; FONSECA, Thais Nívia de L. Censura e mercê: os pedidos de leitura e posse de livros proibidos em Portugal no século XVIII. Revista Brasileira de História da Ciência, v. 4, n. 2, p.139-154, jul/dez. 2011.

FUCKNER, Creusa M. Lar escola Dr. Leocádio José Correia: história de uma proposta de formação na perspectiva educacional Espírita (1963 - 2003). Tese (doutorado), Programa de Pós-graduação em Educação, Universidade Federal do Paraná, Paraná, 2009. Disponível em:

https://www.acervodigital.ufpr.br/handle/1884/46520. Acesso em 18 jan. 2015.

FURET, François; OZOUF, Jacques. Lire et écrire: l'alphabétisation des français de Calvin à Jules Ferry. Paris: Minuit, 1977. 


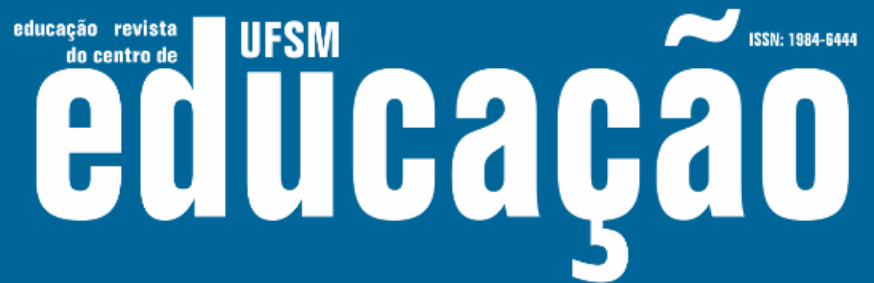

ISSN: 1984-6444 | http://dx.doi.org/10.5902/1984644438126

GALVÃO, Ana Maria de Oliveira. Oralidade, memória e narrativa: elementos para a construção de uma história da cultura escrita. In: GALVÃO, Ana Maria de Oliveira; MELO, Juliana Ferreira de; SOUZA, Maria José Francisco; RESENDE, Patrícia Cappucio (Orgs.). História da cultura escrita: séculos XIX e XX. Belo Horizonte: Autêntica, 2007.

GALVÃO, Ana Maria de Oliveira. História das Culturas do Escrito: tendências e possibilidades de pesquisa. In: MARINHO, Marildes; CARVALHO, Gilcinei Teodoro (Orgs.). Cultura escrita e letramento. Belo Horizonte: Editora da UFMG, 2010.

GIL, Marcelo Freitas. O Colégio União Espírita de Pelotas: primeiras descobertas. Revista Brasileira de História das Religiões, Maringá (PR) v. V, n. 15, jan. 2013. Disponível em: Disponível em: http://www.dhi.uem.br/gtreligiao/pub.html. Acesso em: 12 abr. 2015.

GRUZINSKI, Serge. O pensamento mestiço. Tradução Rosa Freire d'Aguiar. São Paulo: Companhia das Letras, 2001.

INCONTRI, Dora. A educação segundo o espiritismo. São Paulo: Comenius, 2001.

JOHANSSON, Egil. The history of literacy in Sweden. In: GRAFF, Harvey J.

(Ed.) Literacy and historical development: a reader. Carbondale, II.: Southern Illinois University Press, 2007, p.238-271. (Data da publicação original: 1977).

KARDEC, Allan. O livro dos médiuns ou Guia dos médiuns e dos evocadores: espiritismo experimental. Tradução de Guillon Ribeiro da 49 ed. francesa. 71ed. Rio de Janeiro: Federação Espírita Brasileira, [1861]2003.

LEWGOY, Bernardo. Os espíritas e as letras: um estudo antropológico entre cultura escrita e oralidade no espiritismo Kardecista. Tese (Doutorado), Pósgraduação em Antropologia Social, Faculdade de Filosofia, Letras e Ciências Humanas, Universidade de São Paulo, 2000. Disponível em: https://www.lume.ufrgs.br. Acesso em 21 jun. 2015.

MAGALHÃES, Justino Pereira de. Alquimias da escrita: alfabetização, história, desenvolvimento no mundo ocidental do Antigo Regime. Bragança Paulista, SP: Editora da Universidade São Francisco, 2001.

MALATIAN, Teresa. Narrador, registro e arquivo. In: PINSKY, Carla Bassanezi; LUCA, Tania Regina de (Org.). O Historiador e suas fontes. São Paulo: Contexto, 2009. 


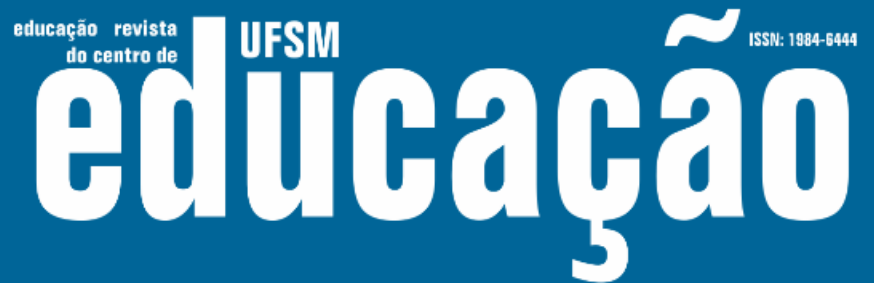

ISSN: 1984-6444 | http://dx.doi.org/10.5902/1984644438126

MARCÍLIO, Maria Luiza. Os registros paroquiais e a história do Brasil. Revista Varia Historia, n.31, p.13-20, jan. 2004. Disponível em: http://www.variahistoria.org/. Acesso em: 21 jul.2016.

REIS, Joseni P. Meira. Letramento em uma instância religiosa: o caso do Centro Psychico de Caetité, Bahia (1905-1930). Tese (doutorado). Programa de PósGraduação em Educação. Universidade Federal de Minas Gerais, Belo Horizonte, 2018. Disponível em: http://www.bibliotecadigital.ufmg.br/dspace/handle/1843/BUOS-BA7NDQ. Acesso em: 12 fev. 2019.

SOARES, Ana Lorym. Produção, circulação e recepção da "Literatura Espírita" no Brasil nas décadas de 1930 e 1940. VII Simpósio Nacional de História Cultural. História Cultural: escritas, circulação, leituras e recepções, Universidade de São Paulo, 2014. Annais do VII Simpósio Nacional de História Cultural. Disponível em: http://gthistoriacultural.com.br/VIIsimposio/anaistc.php?menu=5 ISBN: 978-85-67476-124, 2015>. Acesso em: 16/07/2016.

SOARES, Magda Becker. Letramento: um tema em três gêneros. Belo Horizonte: Autêntica, 2006.

SOUZA, Maria José de. Modos de participação nas culturas do escrito de uma comunidade rural no norte de Minas Gerais. Tese (Doutorado), Programa de Pósgraduação em Educação, Conhecimento e Inclusão Social, Universidade Federal de Minas Gerais, Belo Horizonte, 2009. Disponível em:

http://www.bibliotecadigital.ufmg.br/dspace/handle/1843/BUOS-8R2JCY. Acesso em 23 abr. 2015.

STREET, Brian. Literacy in Theory and Practice. Cambridge: University Press, 1984.

VEIGA, Cynthia Greive. A escolarização como processo de civilização. Revista Brasileira de Educação, n.21, 2002.

VIÑAO FRAGO, Antonio. Alfabetização na sociedade e na História: vozes, palavras e textos. Tradução Tomaz Tadeu da Silva et al. Porto Alegre: Artes Médicas, 1993.

\section{Notas}

1 Este artigo é parte da tese de doutorado intitulada Letramento em uma instância religiosa: o caso do Centro Psychico de Caetité, Bahia (1905-1930) (REIS, 2018). 


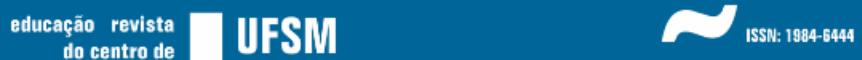

ISSN: 1984-6444 | http://dx.doi.org/10.5902/1984644438126

2 O município está localizado na zona fisiográfica da Serra Geral, situado na Serra do Espinhaço, no Sertão baiano. A cidade encontra-se a 757 quilômetros da capital do estado.

${ }^{3} \mathrm{O}$ conceito de letramento é utilizado numa perspectiva ampla, conforme apresenta Soares (2006), ao defender que, em alguns casos, o sujeito pode ser considerado letrado na medida em que faz usos sociais da escrita, sem necessariamente ser alfabetizado. No caso do presente estudo, letramento religioso se refere às ações que aconteciam no Centro Psychico ou que a ele estavam vinculadas, que tinham a mediação da palavra escrita.

${ }^{4}$ Para uma síntese desses estudos, ver, entre outros, Furet e Ozouf (1977) e Magalhães (2001).

${ }^{5}$ Entre os trabalhos que estudaram essas relações em um nível mais amplo, destacase aquele realizado por Furet e Ozouf (1977), que mostra os contrastes entre a França do Sul, católica e pouco alfabetizada, e a França do Norte, protestante e alfabetizada. Outro estudo que merece destaque é o de Egil Johansson (2007/1977) sobre o caso emblemático da Suécia, país que teve, no século XVIII, a quase totalidade de sua população alfabetizada, sem que houvesse um sistema de ensino estruturado.

${ }^{6}$ É o caso do trabalho de Brian Street (1984) e, posteriormente, de pesquisadores agrupados em torno dos New Literacy Studies, que pesquisaram, ao estudar o caso do Irã e de outros países muçulmanos, as relações entre islamismo e cultura escrita.

7 Galvão (2010) constatou, em levantamento bibliográfico realizado em 2010, que apenas $1 \%$ das teses e dissertações realizadas sobre história da cultura escrita no Brasil, problematizavam o papel das igrejas como agentes de letramento. Para o caso do catolicismo, uma das exceções é o trabalho de Souza (2009), que buscou compreender como um grupo de rezadeiras e benzedores, adultos com breves experiências de escolarização, constroem modos de participação na cultura escrita em uma comunidade rural do Norte de Minas Gerais. Para o caso do candomblé, ver o instigante trabalho de Castillo (2010).

${ }^{8}$ Ver, entre outros, Aubrée e Laplantine ([1990]2009).

9 Uma das exceções, para a contemporaneidade, é o estudo de Lewgoy (2000).

10 Ver, entre outros, Aubrée e Laplantine ([1990]2009).

${ }^{11}$ Uma das exceções, para a contemporaneidade, é o estudo de Lewgoy (2000). 


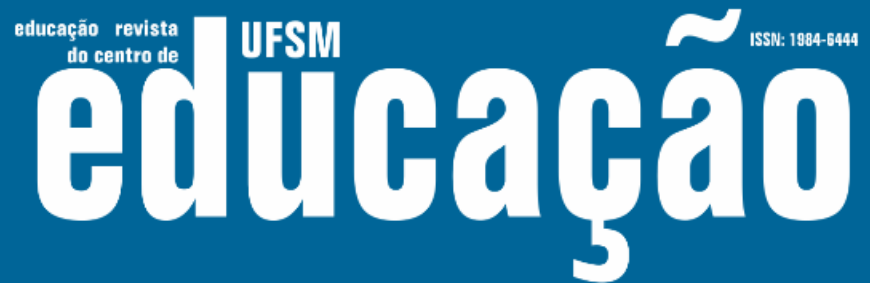

ISSN: 1984-6444 | http://dx.doi.org/10.5902/1984644438126

${ }^{12}$ Denominamos de eventos de letramento qualquer situação, que pode ser observada empiricamente, mediada pela presença do escrito, mesmo que seja marcada também pelo oral, pelo gestual e por outras dimensões da linguagem. As práticas de letramento, por sua vez, não podem ser empiricamente observáveis e dizem respeito a formas culturais gerais de utilização do escrito que as pessoas colocam em jogo em um evento de letramento (BARTON, 1991). É o caso, por exemplo, das práticas de letramento religiosas, escolares, comerciais, etc.

${ }^{13}$ Consideramos esses escritos como documentos que foram produzidos com objetivo e finalidade determinados num contexto específico, portadores de uma prática cultural letrada.

${ }^{14}$ Ver o clássico estudo de Cavalcanti ([1983] 2008).

15 Mantivemos a grafia das palavras conforme os registros da documentação pesquisada.

${ }^{16}$ Bezerra de Menezes, ao criar a Escola de médiuns, em 1890, no Rio de Janeiro, tinha como objetivo formar os próprios sacerdotes espíritas, necessários e responsáveis pela propaganda do Espiritismo em terras brasileiras, além de buscar um "método de salvação capaz de produzir o auto-aperfeiçoamento" (ARRIBAS, 2010) Assim, a mediunidade tornava-se um meio de salvação espírita, devendo, entretanto, pautar-se por alguns princípios como, por exemplo, ser mais educada. A utilização desses recursos visava, sobretudo, produzir uma mediunidade de modo a se distinguir propositadamente dos êxtases das religiosidades indígenas e afro-brasileiras. Vê-se que os espíritas buscavam, então, adotar certa distinção às suas práticas e gestuais, se comparadas às outras formas de manifestações espirituais existentes no campo religioso brasileiro.

17 Ver o trabalho de Dora Incontri (2001).

${ }^{18}$ Sobre espíritos obsessores, ver o já citado estudo de Calvacanti ([1983] 2008).

19 Método criado pelo médico alemão Samuel Hahnemann (1755-1843), que tem como princípio básico: curam-se os semelhantes, pelos semelhantes. O espiritismo adota a homeopatia e a torna uma prática de caridade, oferecendo atendimento médico homeopático aos necessitados. Esse foi um dos meios utilizados pelos espíritas para se legitimar, tanto em relação aos enfrentamentos internos, quanto aos externos (DAMAZIO, 1994). 


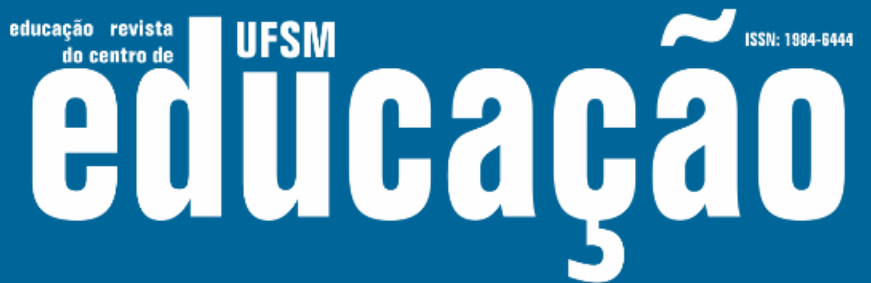

ISSN: 1984-6444 | http://dx.doi.org/10.5902/1984644438126

20 Segundo Marion Aubrée, acredita-se corresponder ao que no começo do Espiritismo se chamava ouija, uma espécie de tábua onde estavam escritas as letras do alfabeto e os números de zero a nove. Esse objeto foi utilizado quando a sessão espírita passou dos golpes dados pelas mesas, que eram ligados à tecnologia telegráfica, para as mensagens escritas através do ouija e depois para método mais prático e rápido, que foram as psicografias, ou as falas diretas dos médiuns (Informação fornecida por Aubrée durante a banca de qualificação do trabalho, UFMG, dezembro, 2017).

21 Sobre a função dos médiuns receitistas, Kardec informa que eles "têm a especialidade de servirem mais facilmente de intérpretes aos Espíritos para as prescrições médicas" (KARDEC, [1861] 2003, p.266).

22 Com relação às práticas homeopáticas realizadas na Bahia, ver o trabalho de Araújo, 2015.

${ }^{23}$ Sobre essa questão, ver: Damazio (1994), Del Priore (2014) e Arribas (2010).

24 Havia na comunidade caetiteense práticas culturais que envolviam diferentes formas de registro de uma escrita específica para essa fase da vida (CARNEIRO, 2011).

25 Ver o trabalho de Marcílio (2004).

26 João Gumes. Carta enviada ao Centro Psychico. Caetité 18 de novembro de 1906. Acervo do Centro Espírita Aristides Spínola

27 João Gumes. Carta enviada ao Centro Psychico. Caetité 18 de novembro de 1906. Acervo do Centro Espírita Aristides Spínola

${ }^{28}$ O Estatuto do Centro foi aprovado em 05 de junho de 1928.

${ }^{29}$ Acta, 14/04/1911.

${ }^{30}$ A doutrinação dos comportamentos dos adeptos do Centro Psychico insere-se no conjunto de propostas mais amplas, como as apresentadas pelo Estado Brasileiro do final do século XIX e início do XX, que tinham como propósito civilizar a população. Veiga (2002) analisa como o Estado apropriou-se dos saberes elementares, a fim de fazer com que a escolarização pudesse impor modelos de comportamentos característicos de uma sociedade aristocrático-burguesa e adotar novas práticas civilizatórias extensivas a toda a sociedade, transformando coerções externas em coerções internas. Nessa perspectiva, além da escola, outras instituições, como as religiosas, a exemplo, o Centro Psychico, também cumpriam esse papel civilizatório, educativo e disciplinador. 


\section{Aitloapẫ}

ISSN: 1984-6444 | http://dx.doi.org/10.5902/1984644438126

31 Para um aprofundamento dos significados atribuídos aos termos instruir e educar no século XVIII, ver Denipoti; Fonseca (2011).

32 Acta, 02/04/1929.

\section{Correspondência}

Joseni Pereira Meira Reis - Avenida Universitária Vanessa Cardoso e Cardoso S/N, Ipanema, CEP: 46.430-000, Guanambi, Bahia, Brasil.

\section{(c) $(1) \Theta$}

This work is licensed under a Creative Commons Attribution-NonCommercial 4.0 International (CC BY-NC 4.0) 